\title{
Mosasaurs, Limpets or Diagenesis: How Placenticeras Shells Got Punctured
}

\author{
Adolf Seilacher ${ }^{1}$ \\ With 8 Figures

\begin{abstract}
Claimed mosasaur bites in Upper Cretaceous Placenticeras shells from the Western United States are reinterpreted as limpetmade pits that became punctured by compactional pressure and beveled during diagenesis.
\end{abstract}

Key words: Ammonite taphonomy, Upper Cretaceous, mosasaurs, limpets

\section{Zusammenfassung}

Die von Kauffman \& Kesling (1960) als Mosasaurier-Bisse gedeuteten Perforationen in oberkretazischen Ammonitengehäusen werden auf die Raspeltätikeit patellider Schnecken zurückgeführt. Diese besiedelten wahrscheinlich nekroplanktonische Gehäuse und lebten hauptsächlich von schalenbohrenden Algen. Erst diagenetische Prozesse haben das Durchbrechen der ursprünglichen Fressdellen sowie die Bördelung der Bruchränder bewirkt.

Schlüsselwörter: Ammoniten, Oberkreide, Mosasaurier, Mützenschnecken, Taphonomie

\section{"Bitten Ammonites" Stories}

When Kauffman \& Kesling (1960) published a Placenticeras bitten by a mosasaur, it was the sensation of the day: two giants of the Cretaceous sea in combat! Was this a clue to the big extinction? Today we believe that the real culprit came from outer space. Nevertheless the specimen (Fig. 6A, now housed in the Museum of Paleontology in Ann Arbor, Michigan, is commonly cited as a classical example of past biotic interactions. In the wake of this discovery, museums all over the US vied for similar specimens. One of them (Fig. 5) is on display in Yale's Peabody Museum, where I am now a curator.

The impact of Kauffman \& Kesling's publication (elaborated in Kauffman 1990) was not restricted to North America. At that time I was in Tübingen (Germany) and wondered whether this evidence could not be evaluated as a "fossil experiment", telling us something about the rigidity of ammonite shell material? Accordingly our technician (Fritz Kern) constructed an iron "mosasaur plier" (Fig. 1), with which we attacked present-day Nautilus and Argonauta shells - the body chamber filled with soft modeling clay to hold fragments together. The resulting holes punched right through the shell in Nautilus, but in Argonauta they were surrounded by a halo of small radial and concentric fractures - much like the punctures figured by Kauffman \& Kesling. Our conclusion at the time was that the shell had been less stiff in ammonites than in Nautilus, behaving rather like the more flexible shell of Argonauta.

There was also another reaction. The forester Otto Linck, a master in many fields and an avid paleontologist (he had been awarded an honorary doctorate by the Tübingen University in 1952), found Middle Triassic ceratites with aligned holes on both sides. He first thought them to be Nothosaurus bites. The main difficulty with this interpretation was that ceratites are mere steinkerns that have diagenetically lost their aragonitic shell wall! Closer inspection showed that we deal with a peculiar taphonomic phenomenon (Seilacher 1966): all Muschelkalk ceratites owe their preservation to a particular

\footnotetext{
${ }^{1}$ Kline Geology Laboratory, Yale University, New Haven, P.O. Box 208109, New Haven, CT 06520, USA and GeologischPaläontologisches Institut der Universität, Sigwartstr. 10, 72076 Tübingen, Germany.

Received April 1998, accepted July 1998
} 


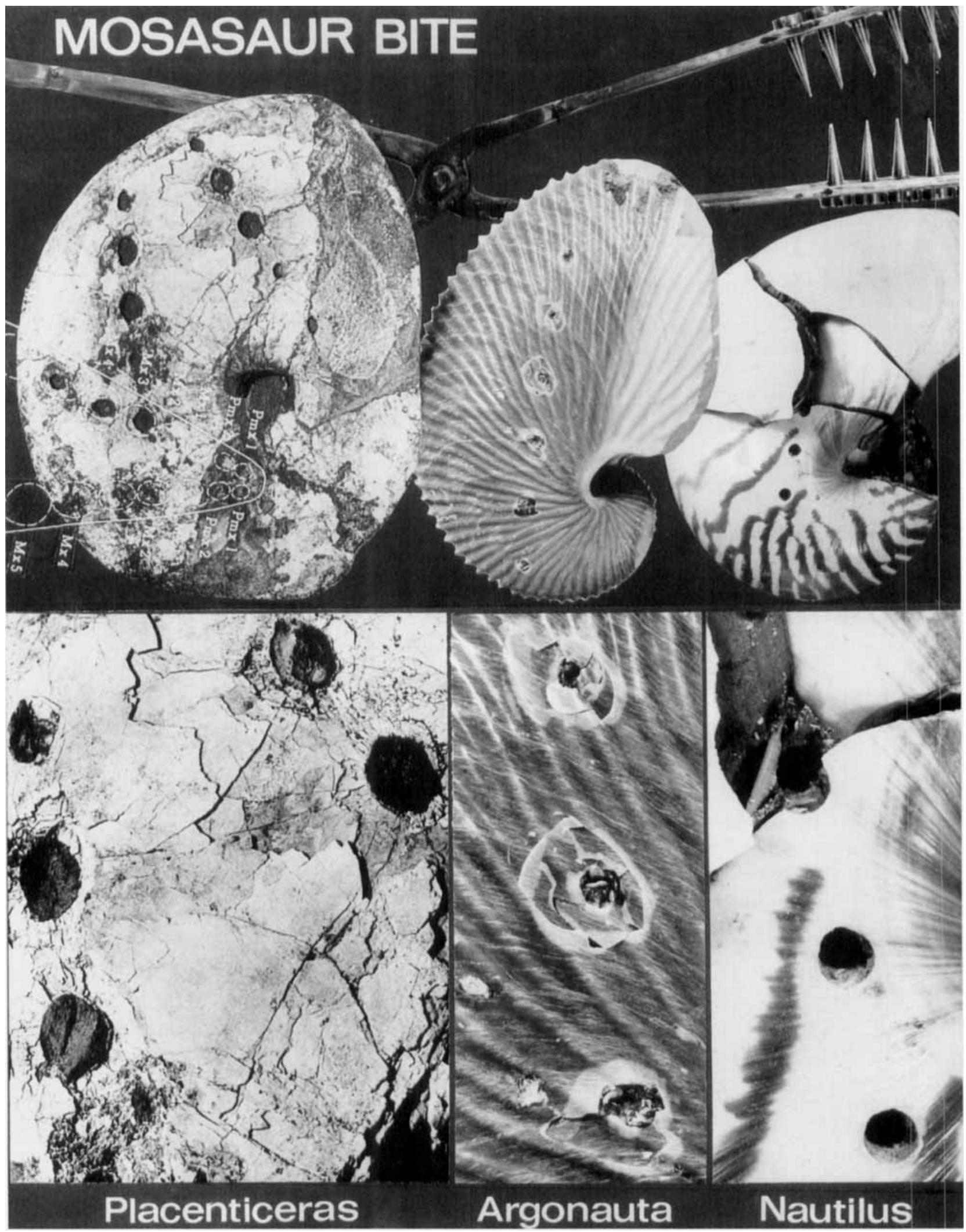

Fig. 1. Bite experiment made in 1965 in order to compare the fracturing behavior of present-day Aragonata and Nautilus with that of the Placenticeras shell figured by Kauffman \& Kesling 1960 
mechanism (draft sedimentation) that filled the chambers of the phragmocone with fine sediment. Being protected by the shell against compaction, this fill sediment became diagenetically cemented earlier than the surrounding matrix. Thus the "prefossilized" steinkern was able to survive subsequent shell dissolution and reworking, retaining all the original details of the internal fill sedimentation. Given this background, the suspected bite marks turned out to be the result of incomplete chamber filling in shells that had become draft-filled in upright position: voids always formed in the highest corners of the chambers - below the septal in the descending part of the spire, and below saddles in the ascending part (Fig. 2). Important as it may have been in other respects, this insight ended the dream of bitten ceratites. Independently, $\mathrm{H}$.

\section{LOBE VOIDS IN MUSCHELKALK CERATITES}
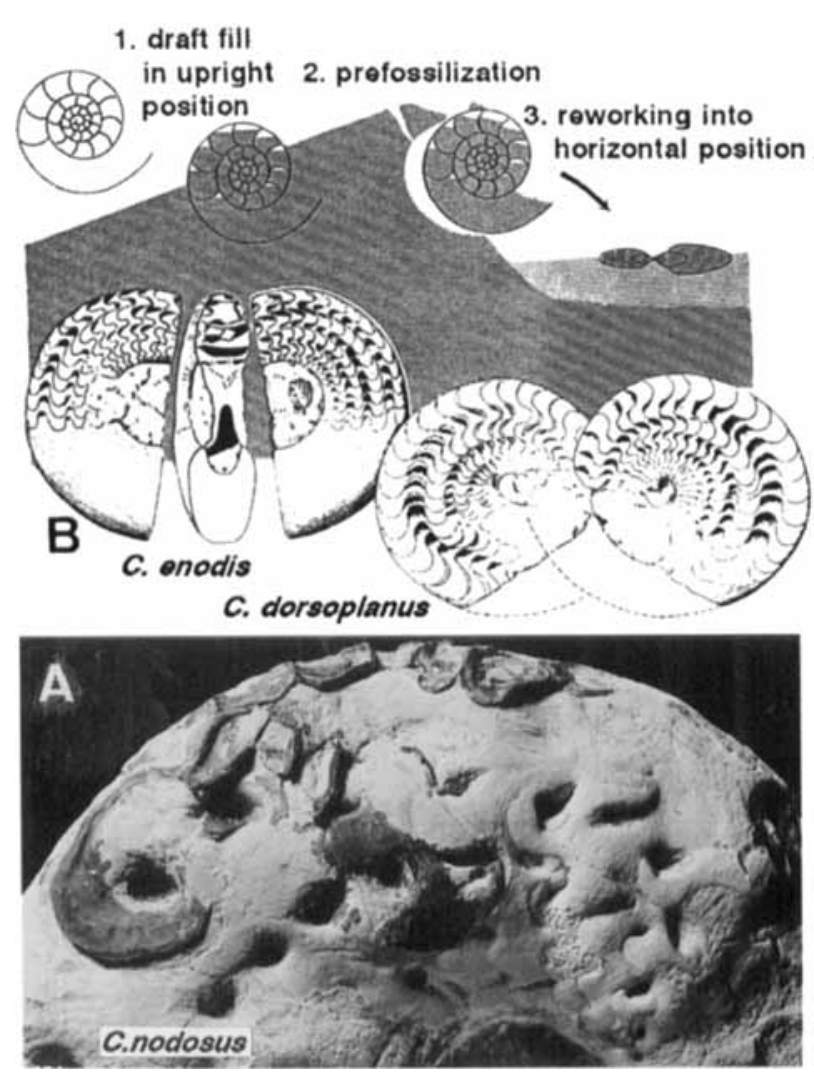

Fig. 2. A: Rather than bite marks, the serial impressions in a ceratite from the German Muschelkalk (M.Triassic) are lobe voids in a shell that became draft-filled in upright position. When the aragonitic ceratite shell became diagenetically dissolved, encrusting calcitic bivalves (Placunopsis) became plastered onto the prefossilized steinkern and pressed into the voids. B: Since the fill sediment became prefossilized into a pressure-shadow concretion, these voids survived not only shell dissolution, but also reworking into the horizontal position indicated by "double suture lines". (From Seilacher 1966)
Keupp (1991) came to a similar conclusion with regard to round punctures in Jurassic ammonites, because they are regularly located at the lateral lobes of the phragmocone.

What then, about the mosasaur bites? Here, first doubt evolved from observations of Japanese paleontologists (Kase et al. 1994). They observed round impressions on large ammonites from Hokkaido and Sakhalin that occur in rocks similar, by age as well as facies, to the Late Cretaceous Pierre Shale of South Dakota, from which Kauffman \& Kesling's specimen had been collected. In their interpretation, the impressions (but rarely holes) are the "homing pits" of associated limpets. Since such pits are found in equal densities on either flank of the ammonite shell, they concluded that these gastropods were attached to the living ammonite. Because limpets typically graze on algal films, this further meant that the particular ammonites must have spent most of their time in the photic zone of the ocean - rather than descending into deeper waters during the day, as present-day Nautilus does. This result, however, was doubted by Westermann \& Hewitt (1995). Only when Tomoko Kase came to complement his observations on material from America, he and Paul Johnston (Royal Tyrrell Museum, Drumheller) realized that in this country limpet pits had largely been considered as mosasaur bites in the wake of Kauffman \& Kesling's publication. But how did they get punctured?

\section{Radular Markings on Albian Ammonites}

It was the merit of Eberhard Voigt (1977) to first call the attention of paleontologists to minute rasping marks preserved on shells of oysters and other mollusks in Jurassic, Cretaceous and Tertiary deposits. Under the ichnogeneric name Radulichnus, he referred them to chitons and docoglossan gastropods that not only grazed on a surficial algal film, but also on endolithic algae, whose presence is documented by microscopic shell borings. The radulae of these mollusks are specially adapted to scratching hard substrates by relatively stout teeth, whose tips are enforced in chitons by apatite and magnetite (Löwenstam 1967). They also differ from other (e.g. taenioglossan) radulae by acting like the fixed prongs in a rake, rather than rotationg laterally during the bite. Accordingly, individual bite marks reflect the chainsaw-like forward motion of the radular band, with the number of parallel 
scratches corresponding to the number of teeth in each transverse row. In addition, the pendulum movement of the head and the creeping of the foot result in the arrangement of successive bite marks into broad meanders, which may transform into arcuate rows in dense, fan-like arrays.

The association of Radulichnus with ammonites was first reported by Akpan et al. (1982) from the Albian of Great Britain. Based on observations in modern patellids and the presence of fitting shells in the same beds they identified Acmaea tenuistriata as the maker (Fig. 3). Here, the raspings are exquisitely preserved as fans on the phosphatic steinkerns of hoplitids. Since they are restricted to the body chamber sections, the limpets must have lived inside dead ammonite shells. Assuming that these shells were lying on the bottom, the authors concluded that water depth was only $8-30 \mathrm{~m}$ - shallow enough for boring algae to receive sufficient light for photosymbiosis.

\section{Limpet Raspings on the Inside of a Placenticeras Body Chamber}

Turning to the Upper Cretaceous Pierre Shale, a specimen in the Peabody collection (Fig. 4) is of particular interest, (1) because it comes from the same horizon as the original "Mosasaur bites"; (2) because it combines normal Radulichnus fans with a variant resembling the limpet-made "homing pits" described by Kase et al. (1994).

In this case we deal with part of the body chamber of a large Placenticeras. On the inner side (Fig. 4B) it bears the sutural impressions from the previous whorl and on the convex outer side (Fig. 4A) the molds of the radula marks, which are still partly covered by original aragonitic shell material. So it is clear that these raspings were made inside the body chamber after the death of the ammonite and before this unsupported part of the shell became crushed by compaction. There is also no doubt about the maker: a fracture on the inside of the specimen (Fig. 4B) reveals a limpet (Acmaea occidentalis) that was still attached. This fits the shape of the

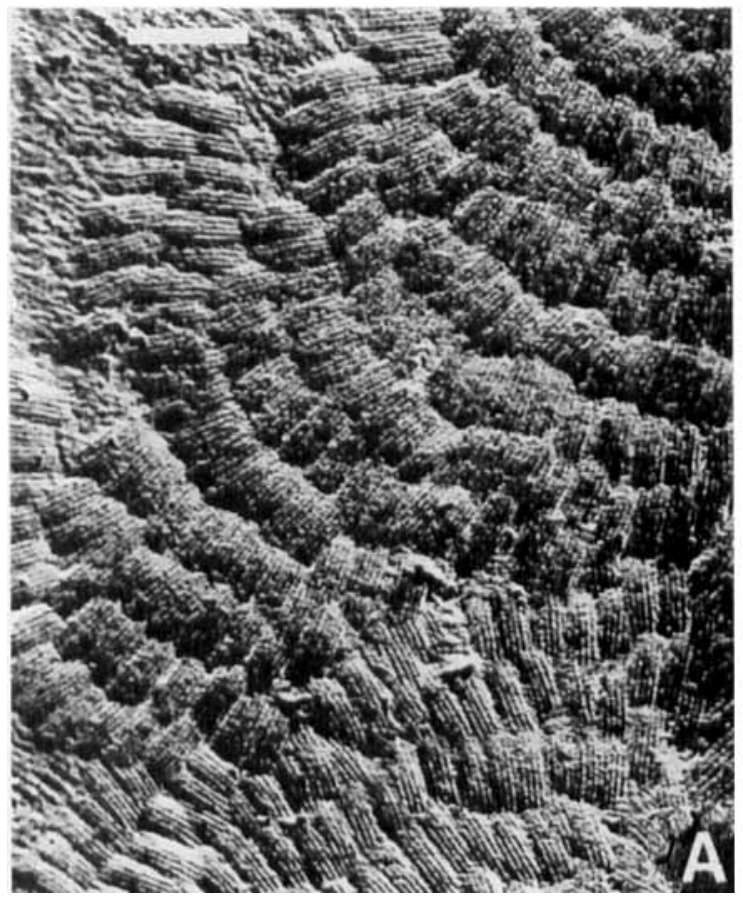

by Acmaea virginica on Dosinia

(Recent)

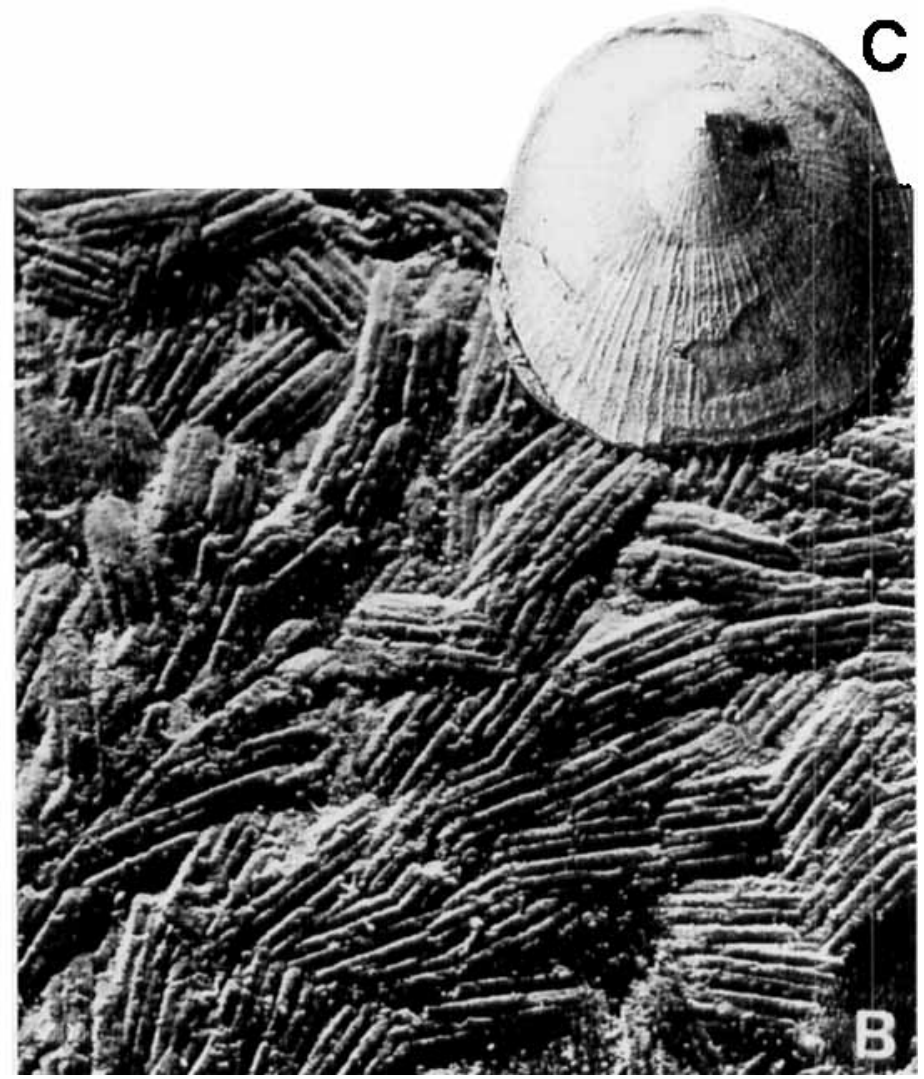

by Acmaea tenuistriata on hoplitid ammonite (M.Albian)

Fig. 3. Limpet raspings on modern shells $(\mathbf{A})$ and the phosphoritic mold of a Lower Cretaceous ammonite (B) show the same fan-shaped arrangement of bites and the presence of 6 teeth in each row of the radula (From Akpan et al. 1982) 


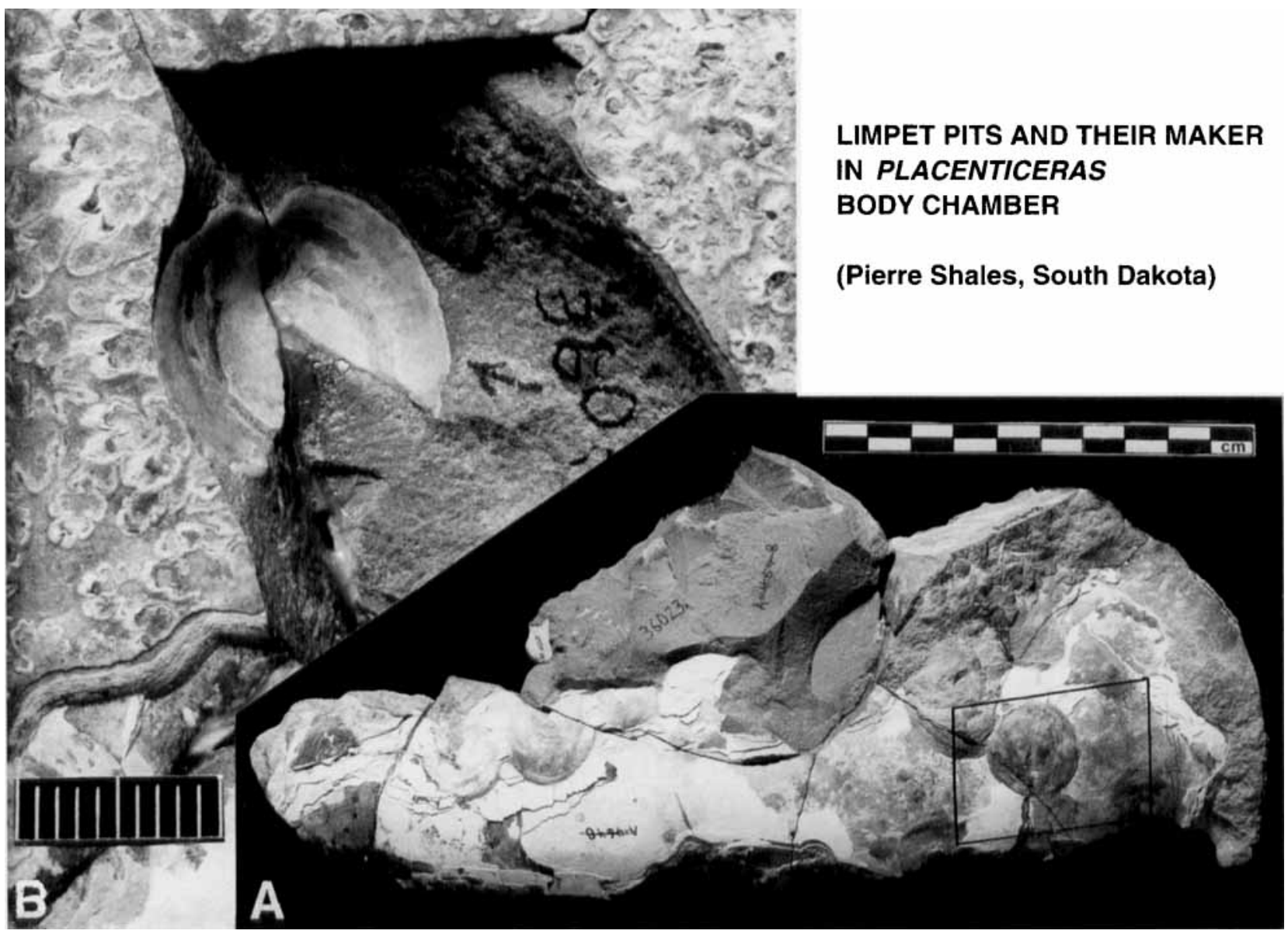

Fig. 4. A: Fragment of Placenticeras from the Upper Cretaceous Pierre Shale of South Dakota(YPM 36023) showing casts of limpet pits made on the inside of the body chamber. Outlined: detail shown in Fig. 6C. Aperture is to the left. B: Reverse side with Acmaea occidentalis (Hall \& Meek) and serpulid worm attached to previous whorl in the same body chamber (YPM 36020; phot. W. Sacco)

raspings: like in the Albian form they consist of six parallel scratches corresponding to the six radular teeth in some present-day Acmaea species (Fig. 6B).

What makes the difference, is behavior. In addition to flat, fan-shaped arrays and individual bites strewn over the surface, this specimen shows a number of deep circular pits, in which identical markings are arranged in a perfectly radial fashion. It is not clear whether the limpet could excavate such a pit while sitting on it and rotating in the act or whether the animal had to rotate around the pit. In any case, a program different from that of meandric grazing was required. Since neither in a floating shell nor in one lying on the sea bottom tides were a major factor, it is also questionable whether these pits served primarily for homing. The alternative (that they merely represent another mode of grazing on shell-boring algae) would mean that one limpet could make several pits in succession. In this case the actual population in this limited biotope could have been considerably smaller than the number of pits oberserved.

Another problem is the ichnotaxonomic treatment of such dimorphism. Following a strictly morphological procedure, the pits should be given an own ichnospecific name, while in a more biological approach, they could be treated as behavioral variants of Radulichnus inopinatus Voigt. More important are the general conclusions that can be drawn from this specimen:

1. Because the pits are on the inner surface of the body chamber, they could not have been made during the lifetime of the ammonite.

2. Because the Pierre Shale represents a largely anoxic environment, the raspings are unlikely to have been produced after the shell had sunk to the bottom.

3. This implies long necroplanktonic drifting, which is known from Nautilus shells, but has been questioned for ammonites on taphonomic grounds (Seilacher \& LaBarbera 1995). 


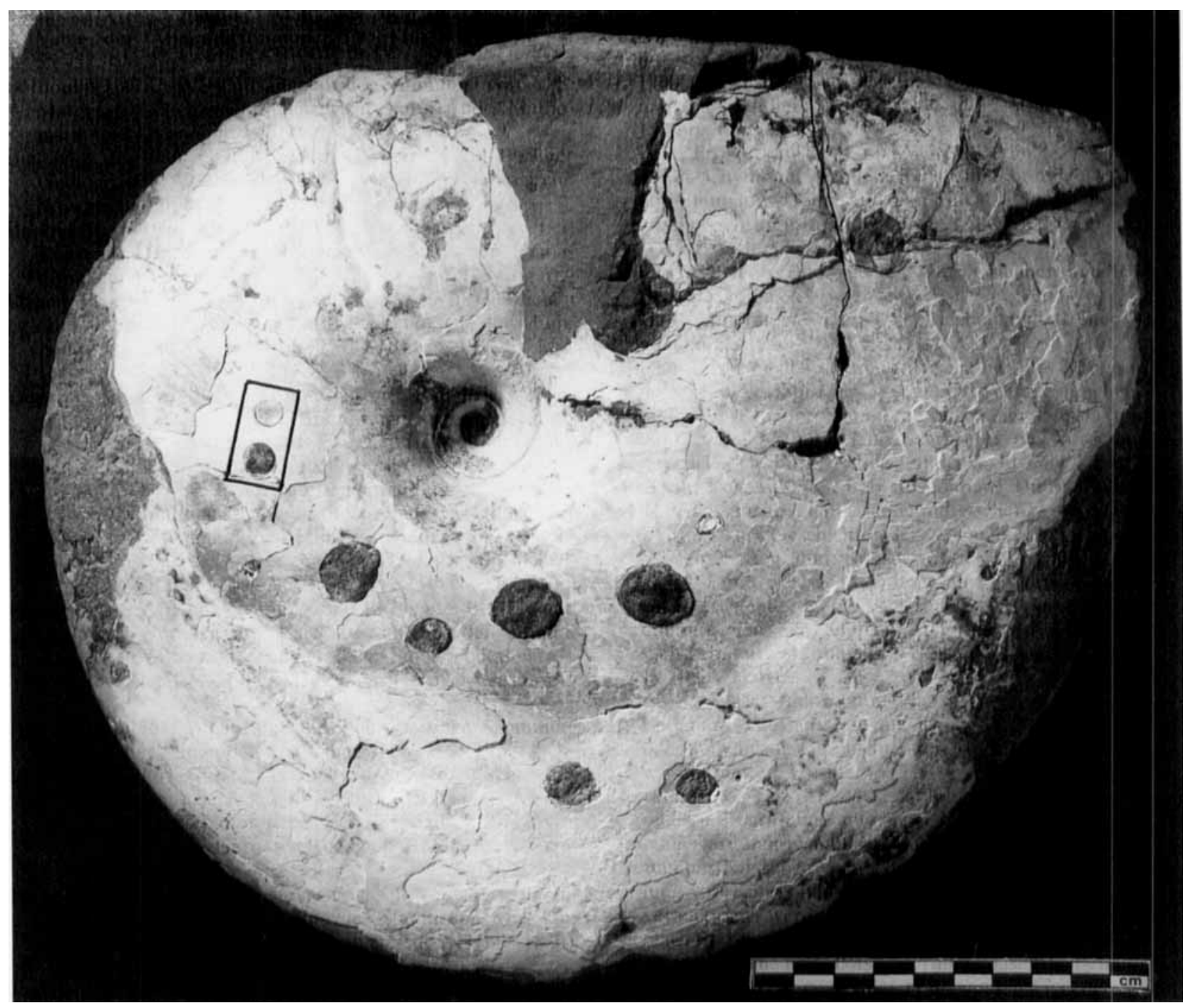

Fig. 5. Phragmocone of "bitten" Placenticeras with non-aligned punctures (YPM 36058). See Fig. 6C for drawings of reverse side and of outlined area with incomplete puncture (phot. W. Sacco). Scala bar $=10 \mathrm{~cm}$

\section{Diagenetic Puncturing}

The Placenticeras specimen in the Dinosaur Hall of the Yale Peabody Museum (Fig. 5) has traditionally made visitors shiver with the thought of a mortal attack. Although some of the "bitemarks" are possibly artifacts, most of them well fit a mosasaur tooth. They also are clearly punctures rather than mere pits, the dark fracture of the sediment plug contrasting sharply with the white iridescent shell surface. There is even another phenomenon familiar from the Kauffman \& Kesling specimen: the original punctures (but not the ones suspected to be artificial) are surrounded by a halo of small shell fragments sloping inward towards the hole. Also the body chamber is crushed. So, why should we not believe in the mosasaur story?
The crucial counterargument is the lack of hole alignment and of correspondence between patterns seen on the two flanks of the ammonite (Fig. 6C). Admittedly, fracture haloes and puncturing are difficult to explain by limpet activities. In this case, the limpets were, like in the Japanese specimens, certainly living on the outer shell surface of the phragmocone, inside which wall space would have been too limited by the intricately folded septa. But if they lived on the outside, why should the limpets puncture the shell and thereby sink their float - no matter if it was a living ammonite or only its dead drifting shell? Also, limpets were unable to press-in the margin of the holes the way a mosasaur tooth could.

The answer comes from a small pit (Fig. 6C) that failed to puncture the shell. Nevertheless it has a depressed brim set off from the bottom 
part by a perfectly circular ring-fracture, which is enhanced by dark sediment intruded into the crack. Under the microscope it can be seen that this sedimentary "ring dyke" widens at depth; so the disk-like shell fragment is bounded by conical fractures, as typically form in brittle materials under point load. This suggests that it was not the limpet that punctured the shell, but sediment pressure transformed into a point load by the template of the limpet pit. In this scenario, the incomplete puncture (Fig. 6C) represents the first stage in a process that would normally have led to a circular hole, through which sediment could enter the shell cavity (Fig. 6D).

This hypothesis could be verified, if future collectors would save not only the ammonite positive, but its negative impression as well. Ammonites in which shell aragonite is still preserved, tend to break along laminae within the shell. Thus the critical outer surface remains hidden under a shell layer in the countermold. If this aragonitic material would be removed by weak acid or genthe brushing, one would probably see the molds of the raspings also on the outside. This test may fail in punctured pits; but there will always be shallower pits that escaped such deformation.

\section{Are there any true Bites?}

Having discussed the compactional puncturing of presumed limpet pits, we must return to the Kauffman \& Kesling specimen. Is it possible that the radially fractured halo around its punctures is also a diagenetic artifact - rather than having been produced by the broad base of the mosasaur tooth as the authors suggested?

Here it is important to note that during compaction, a sediment-filled ammonite shell acts as a pressure vessel. This is why in ceratites the uncompacted fill sediment became prefossilized into a pressure-shadow concretion. Ceratite body chambers had a similar effect - but only in their rear parts, because sediment pressure could enter from the aperture. Therefore ceratite steinkerns never preserve the apertural margin of the shell. Correspondingly, apertural parts of aragonitically preserved ammonites in the mid-Jurassic Opalinus Clay (Seilacher et al. 1976) are always crushed over the petering-out body chamber concretion. Thus, if the Pierre Shale ammonites had a similar preservational history, the fracturing of their body chamber may also be a diagenetic effect, having nothing to do with the predator's terminal bite on the ammonite's soft parts.
The diagenetic effect of holes in such a pressure vessel is well illustrated by internal molds of echinoids from the Upper Cretaceous chalk (Fig. 7). In this case the fill sediment has become prefossilized by silica rather than carbonate. In the resulting chert steinkerns one observes, instead of the expected projections, hemispherical impressions below the original openings (ambulacral pores, mouth, anus). The reason is that ambient pressure entered through the hole and inhibited prefossilization in the corresponding pressure halo. In the punctured Pierre Shale ammonites we cannot expect such diagenetic pits to be visible, because all cementation was by carbonate; but if the same principle applied, their fill sediment must at some stage have been softer below and around the punctures. Due to this local inhomogeneity, continued sediment pressure would have produced depressed brims.

Since diagenetic beveling applies to primary as well as secondary holes, it would also be compatible with the mosasaur scenario. Still a limpet origin is more likely also in the Kauffman \& Kesling specimen for the following reasons:

1. Punctures are only in the phragmocone, but not in the body chamber, part of the shell.

2. "Tooth rows" on the two sides of the Kauffman \& Kesling specimen do not completely correspond; the axes of upper and lower jaws are twisted relative to each other (Fig. 6A).

3. Aligned pits occur also in other specimens, but only as single series (Kase et al., submitted). Perhaps this alignment was induced by the waterline on the two sides of a drifting ammonite shell, along which the limpets preferred to home at various stages of buoyancy loss and at respectful distances (P. Johnston pers. comm.).

4. It is very unlikely that two unrelated kinds of shell punctures - one due to limpet pits, the other to mosasaur bites - should be confined to a particular stratigraphic interval and to the same localities.

\section{Conclusion}

The claimed "mosasaur bites" are probably all caused by limpets rasping on necroplanktonic Placenticeras shells, compactional puncturing of the pits and diagenetic beveling of the rims. In contrast, limpet pits inside the body chamber did not get punctured and preserve the original relief, including radial radula marks. 


\section{PUNCTURED PLACENTICERAS}

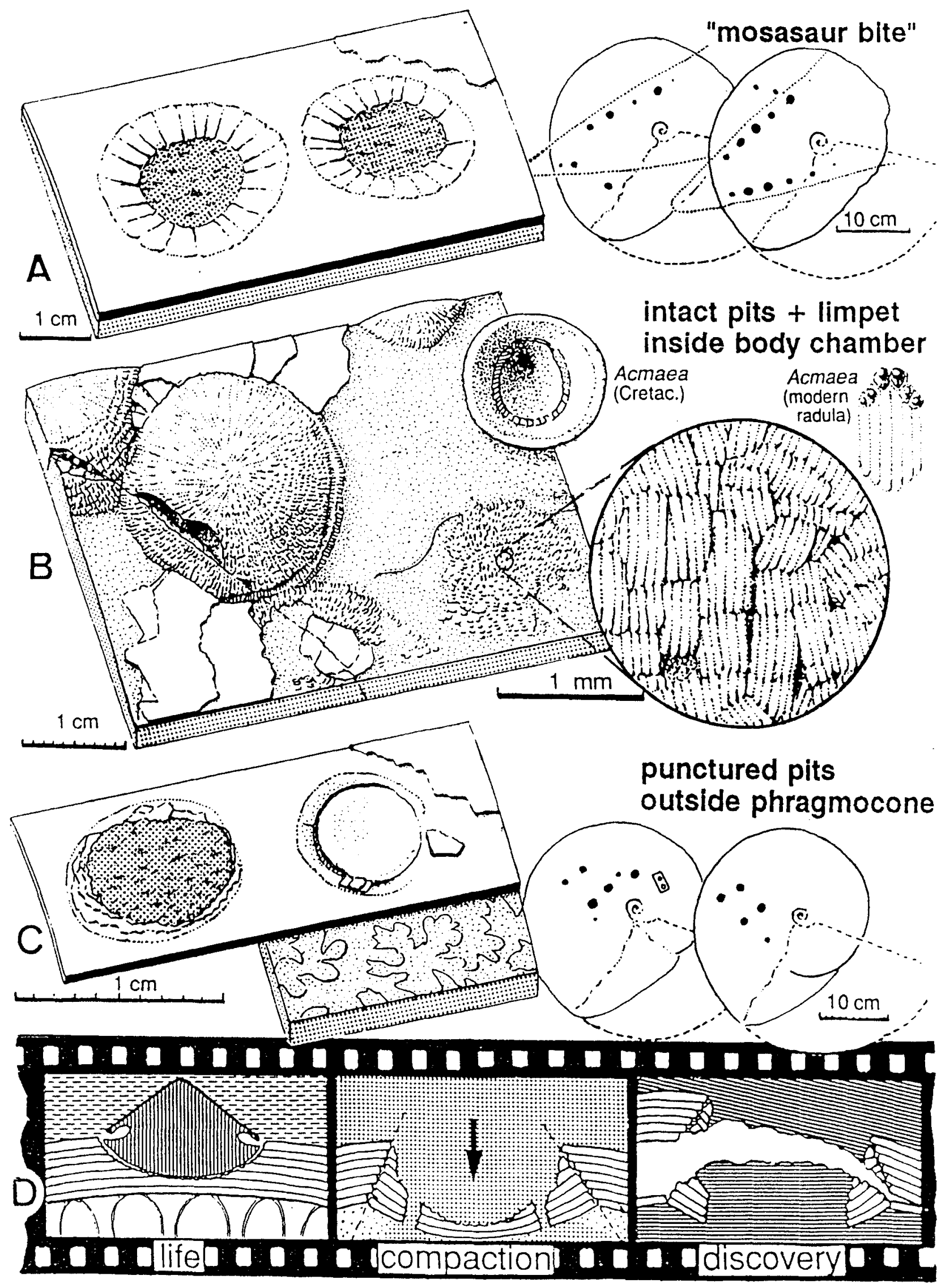




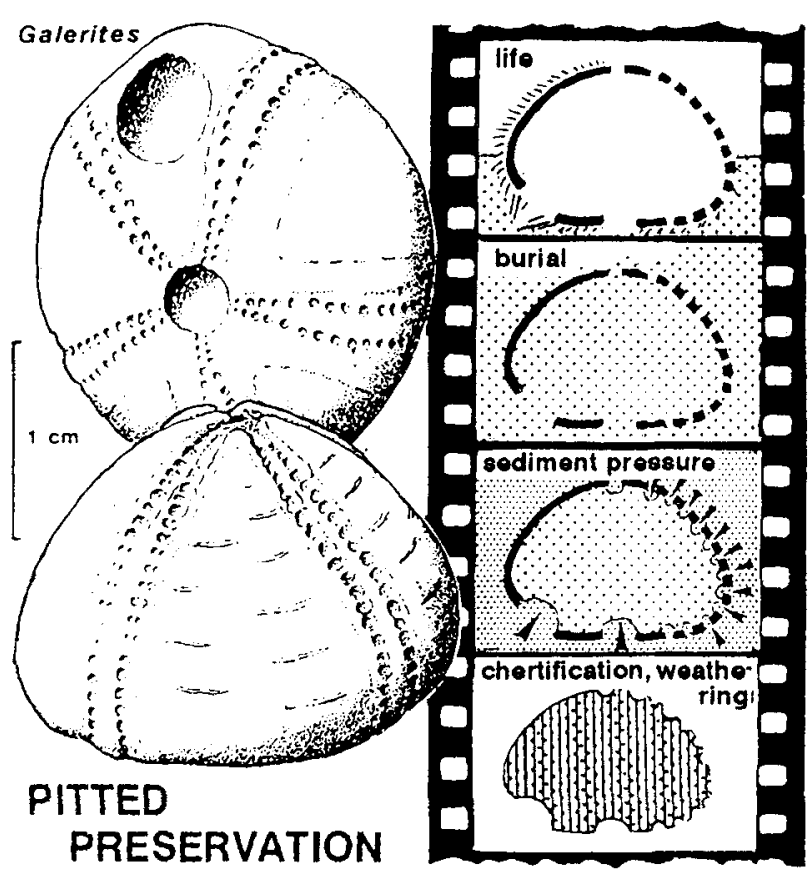

Fig. 7. Internal mold of an irregular echinoid from the Cretaceous chalk of Northern Germany. Original openings in the test appear as sunken pits, because chertification was inhibited by the sediment pressure intruding through them. Similar pressure haloes were probably responsible for the beveled margins of Placenticeras shell punctures. (From Seilacher 1991)

This does not exclude that mosasaurs and other marine reptiles did prey on ammonites; but the result would be shattered shells, in which the fragments are more scattered than in compactional collapse (Fig. 8).

Some colleagues - particularly the owners of high-prized "bitten ammonites" - might be unhappy about this new interpretation. Even worse: in this case, forgery must be blamed on nature rather than on sueable individuals. Yet, while loosing a cherished story, we also gain new insights that should count more than the market prize of a fossil.

Another lesson is that fossils cannot be interpreted adequately without considering the taphonomic overprint. It may have altered the original

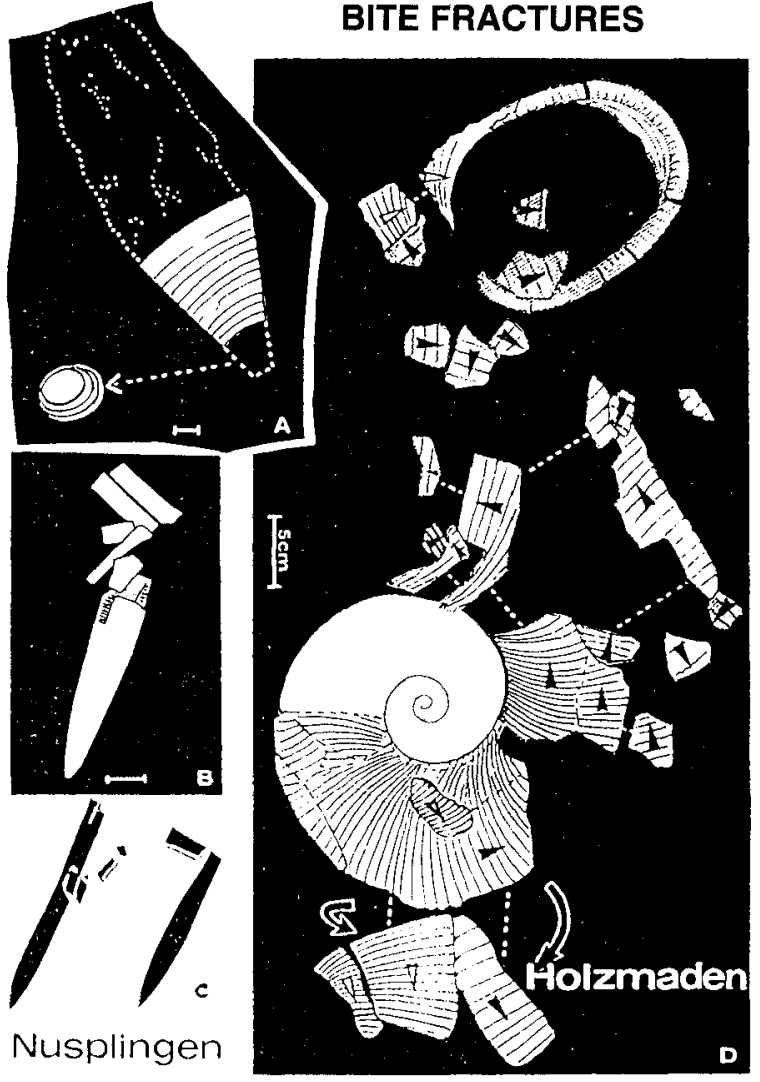

Fig. 8. Scattered fragments of bitten belemnite and ammonite shells suggest that they were still held together by soft parts when reaching stagnant Jurassic sea bottoms (Toarcian bituminous shales, Holzmaden; Tithonian lithographic limestones, Nusplingen, Germany). Crushing by large predators was also instrumental in the preservation of soft parts (A), because it sank carcasses before they could decompose. (From Seilacher \& Wiesenauer 1978)

morphology, but it also added new information to the ancient documents. After all, paleontology is a biological as well as a geological science!

\section{Acknowledgements}

I thank Gerd Westermann for turning my interest to the publication of Kase et al. and Tomoki Kase and Paul Johnston for their suggestion that "mosasaur bites" may, in fact, be

Fig. 6. A. The mosasaur relationship was based on the alignment of punctures and their beveled rims. In the new interpretation, alignment is due to the preferred limpet attachment along successive water lines around a necroplanktonic shell, while puncturing and beveling are diagenetic effects (drawn after Kauffman \& Kesling 1960). B. Round pits and fan-shaped arrays on the internal mold of a body chamber (Fig. 5A) reflect the rasping activity of an associated limpet (Acmaea occidentalis) with six teeth in each radular row. Radial arrangement of raspings in the pits shows that the animal turned around while excavating them. (From specimen in Yale Peabody collection. Raspings: YPM 36023; limpet shell YPM 36020. Radula teeth of modern Acmaea species after MacClintock 1967). C. In the phragmocone part of a large Placenticeras, punctures are not aligned. Having been excavated from the outside, the pits became secondarily punctured and beveled during diagenesis. In the block diagram (outlined in picture of whole shell) the smaller pit is incompletely punctured; nevertheless its margin became beveled by ring fractures (YPM 36058). D. Flow diagram showing (from left to right) limpet in place, compactional puncturing (arrow) as well as beveling and breakage along shell layers, concealing inferred radula scratches on the outer surface 
limpet pits. $\mathrm{I}$ am also indebted to my Yale colleague Cope MacClintock. Being a limpet specialist himself, he called my attention to the crucial radula markings and gave access to the "bitten" ammonite in the Peabody collections under his care. Richard A. Davis (Cincinnati) kindly commented on an earlier version of the manuscript. H. Keupp (Berlin) and an anonymous reviewer made useful suggestions.

\section{References}

Akpan, F. B., Farrow, G. E. \& Morris, N. 1982. Limpet grazing on Cretacous algal-bored ammonites. - Palaeontology 25: $361-367$

Kase, T., Johnston P. A., Scilacher, A. \& Boycc, J. B. (submitted). Alleged mosasaur marks on Late Cretaceous ammonites are limpet (patcllogastropod) home-scars. Geology

Kase, T., Shigeta, Y. \& Futakami, M. 1994. Limpet home depressions in Cretaceous ammonites. - Lethaia 27: 49-58, Oslo,

-.- 1995. Limpet pits on ammonoids living in surface waters: reply. - Lethaia $\mathbf{2 8}(4): 315-316$.

Kauffman, E. G. 1990. Mosasaur predation on ammonites during the Cretaceous - an evolutionary history. In Boucot, A. J. (ed.). Evolutionary Paleobiology of Behavior and Coevolution; 184-189, Elsevier; Amsterdam.

Kauffman, E. G. \& Kesling, R. V. 1960. An Upper Cre taceous ammonite bitten by a mosasaur. -- Contributions from the Museum of Paleontology, University of Michigan 15: 193-248.
Keupp, H. 1991. Biß3marken oder postmortale Implosionsstrukturen? - Fossilien 1991: 275-280.

Löwenstamm, H. A. 1967. Lepidocroite, an apatite mineral in the teeth of chiton. - Science 156: 1373-1375.

MacClintock, C. 1967. Shell structure of Patelloid and Bellerophontoid Gastropods (Mollusca). - Peabody Museum of Natural History, Yale University, Bulletin 22: $1-140$

Seilacher, A. 1966. Lobenlibellen und Füllstrukturen bei Ceratiten. - Neues Jahrbuch für Geologie und Paläontologie, Abhandlungen 125: 480--488.

- 1991. Was Fossilien erzählen, oder: zur Taphonomie und Diagenese von Kreidefeuersteinen. - Fossilien 4: $210-214$.

Seilacher, A., Andalib, F., Dietl, G. \& Gocht, H. 1976. Pre servational history of compressed Jurassic ammonites from Southern Germany. - Neues Jahrbuch für Geologie und Paläontologie, Abhandlungen 152: 307-356, Stuttgart.

Seilacher, A. \& LaBarbera, M. 1995. Ammonites as Carte. sian Divers. - Palaios $10(6)$ : 493-50

Seilacher, A. \& Wiesenauer, E. 1978. Preservational and adaptational history of belemnites. - Neues Jahrbuch für Geologie und Paläontologie, Abhandlungen 145: $145-149$

Voigt, E. 1977. On grazing traces produced by the radula of fossil and recent gastropods and chitons. In Cimes, T. P. \& Harper, J.C. (eds.). Trace Fossils 2: 335-346, Seel House Press.

Westermann, G. E. G. \& Hewitt, R. A. 1995. Do limpet pits indicate that desmoceratacean ammonites lived mainly in surface waters? -- Lethaia 28 (1): 24 